\title{
CURRENT
}

Jurnal Kajian Akuntansi dan Bisnis Terkini

https://current.ejournal.unri.ac.id

\section{PENGARUH EARNING DAN CASH FLOW OPERATION TERHADAP ARUS KAS MASA DEPAN}

\author{
Naz'aina Naz'aina ${ }^{{ }^{*}}$, Chairunnisa Chairunnisa ${ }^{2}$ \\ ${ }^{12}$ Program Studi Akuntansi, Fakultas Ekonomi dan Bisnis, Universitas Malikussaleh, \\ Lhouksemawe \\ *Email: nazaina@unimal.ac.id
}

\begin{tabular}{l}
\hline Keywords \\
\hline Earning, \\
Cash Flow Operation, \\
Future Cash Flow
\end{tabular}

Article informations

Received:

2021-03-17

Accepted:

2021-04-07

Available Online:

2021-04-11

\begin{abstract}
This study is an empirical study that aims to analyze the effect of earning and cash flow operation on future cash flow. The type of data used in this study is secondary data from each companies financial statements in consumer goods sector that listed on Indonesia Stock Exchange in 2014-2018. The number of samples in this study were 27 companies that selected by purposive sampling method. The independent variable used are earning and cash flow operation in 2014-2017, while dependent variable is future cash flow in 2015-2018. The analysis model used in this research is multi linear regression analysis using Eviews 11. 11. The result show that the earning variable has negative and significant effect on future cash flow. The cash flow operation variable has positive and significant effect on future cash flow. Thus, earning and cash flow operation simultaneously have positive and significant effect on future cash flow.
\end{abstract}

\section{PENDAHULUAN}

Consumer goods merupakan sektor usaha yang memproduksi produk-produk yang di konsumsi sehari-hari yakni dalam bidang makanan dan minuman, tembakau, farmasi, kosmetik dan barang keperluan rumah tangga, dan peralatan rumah tangga. Saat ini pertumbuhan sektor industri consumer goods cukup tinggi disebabkan oleh meningkatnya volume permintaan dari masyarakat. Hampir sebagian besar pendapatan yang diperoleh masyarakat dibelanjakan untuk memenuhi kebutuhan mereka sehari-hari.

Sektor consumer goods menjadi incaran para investor untuk melakukan invest karena memiliki kinerja yang baik dari tahun ke tahun. Hal tersebut dapat dilihat dengan jumlah Penanaman Modal Dalam Negeri (PMDN) yang mencapai Rp 38,5 triliun dan PMA atau Penanaman Modal Asing sebesar US\$ 1,97 miliar. Bahkan menurut catatan Kementerian Perindustrian, pertumbuhan industri ini mencapai 9,23\%, jauh di atas pertumbuhan Produk Domestik Bruto (PDB) nasional yang sebesar 5,07\%. Industri ini memberikan kontribusi 
tertinggi dibandingkan sektor lainnya terhadap PDB (www.industrikontan.co.id).

Ditengah keadaan ekonomi global yang tidak menentu dan persaingan yang semakin ketat, banyak ancaman dan risiko yang bisa terjadi. Hal tersebut menyebabkan ketidakstabilan atau fluktuasi pendapatan di perusahaan sektor consumer goods.

Informasi yang tepat dan akurat sangat berguna bagi para pelaku bisnis dalam mempertimbangkan alternatif-alternatif strategi dalam bisnisnya. Kemampuan para pelaku bisnis dalam memprediksi kondisi keuangan perusahaan masa depan sangat diperlukan sebelum membuat suatu keputusan bisnis. Jenis keputusan yang dibuat oleh pengguna laporan keuangan sangat bervariasi, tergantung pada metode pengambilan keputusan, informasi yang dimiliki oleh sumber lain dan kemampuan mereka dalam memperoleh informasi.

Prediksi arus kas masa depan penting dilakukan untuk memberikan gambaran arah operasi usaha dalam ketidakpastian yang dihadapi oleh perusahaan, karena ketidakpastian yang timbul akan berhubungan langsung dan mempengaruhi kelangsungan hidup perusahaan dimasa mendatang. Prediksi arus kas operasi masa depan dapat memperlihatkan prospek perusahaan. Bagi investor arus kas operasi masa depan berguna dalam mengambil keputusan investasi. Jika prospek perusahaan tidak sesuai dengan harapan investor, maka investor akan berfikir untuk menjual saham tersebut.

Laba bersih merupakan penghasilan bersih yang diperoleh oleh perusahaan baik dari aktivitas operasi ataupun diluar aktivitas operasi perusahaan selama satu periode setelah dikurangi pajak penghasilan. Laba bersih mengukur nilai yang dapat diberikan kepada investor dan menunjukkan bagian laba yang akan ditahan di dalam perusahaan dan yang akan dibagikan sebagai dividen. Hal ini memperlihatkan bahwa laba bersih dapat mempengaruhi arus kas operasi di masa depan dengan meningkatnya laba bersih maka meningkat pula arus kas operasi di masa mendatang. Pernyataan ini didukung oleh penalitian yang dilakukan Biniliang et al (2019), Suaidah (2017), Damara 2016), dan Sulistiyawan \& Septiani (2015). Sedangkan penelitian Budiyasa \& Sisdyani (2015) menyatakan bahwa laba bersih tidak berpengaruh terhadap arus kas masa depan

Arus kas operasi menjadi perhatian yang penting karena perusahaan harus menghasilkan arus kas bersih yang positif dari aktivitas operasinya. Perusahaan akan sulit untuk melakukan kegiatan operasi, melunasi pinjaman dan membayar dividen jika perusahaan menghasilkan arus kas yang negatif. Karena arus kas dari aktivitas operasi merupakan sumber pendanaan utama untuk aktivitas operasional perusahaan yang mencerminkan kinerja perusahaan (Damara, 2016). Hal ini sejalan dengan penelitian yang dilakukan oleh Nany, (2013); Rispayanto (2013); Sulistiayan \& Septiani (2015), bahwa besarnya arus kas dari 
aktivitas operasi dapat menentukan kesuksesan atau kegagalan dari suatu perusahaan. Namun peneltian Susanti dan Elen (2021) serta Kusumawardana et al (2013) menyatakan arus kas operasi tidak berpengaruh terhadap arus kas masa depan.

Penelitian ini menarik karena dilakukan pada perusahaan consumer goods yang memproduksi barang-barang kebutuhan sehari hari yang memiliki pertumbuhan yang cukup tinggi, disebabkan oleh meningkatnya volume permintaan dari masyarakat atau konsumen. Berbeda dengan penelitian sebelumnya yang dilakukan pada perusahaan manufaktur. Metode analisis data dalam penelitian ini menggunakan Regresi data panel dengan aplikasi Eviews sedangkan penelitian sebelumnya menggunakan regresi berganda dengan SPSS.

\section{PENGEMBANGAN HIPOTESIS}

\section{Pengaruh Earning dengan Arus Kas Masa Depan}

Besarnya laba yang didapatkan pada tahun berjalan bisa mempengaruhi besarnya arus kas operasi. Laba yang besar menunjukkan penerimaan kas dari pelanggan (dalam kegiatan penjulan) setelah dikurangi dengan biaya maka didapatkan laba, mengingat bahwa penerimaan dari pelanggan adalah salah satu pos dalam arus kas secara tidak langsung akan mempengaruhi arus kas operasi.

Menurut Triyono (2011), laba bersih dapat berpengaruh dalam memprediksi arus kas operasi di masa mendatang karena laba bersih bersifat akrual yang berasal dari laba sebelum pajak ditambah pendapatan lain-lain seperti pendapatan bunga dan dikurangkan dengan beban lain-lain seperti beban bunga dan beban pajak. Menurut Subramanyam (2010) laba akrual dapat digunakan dalam memprediksi arus kas operasi masa depan melalui pengakuan pendapatan yang mencerminkan konsekuensi arus kas operasi masa depan. Misalnya penjualan kredit hari ini meramalkan adanya kas yang akan diterima dari pelanggan di masa depan.

Teori di atas diperkuat dengan hasil penelitian yang dilakukan oleh Yunia \& Ibrahim (2021), Susanti \& Elen (2021), Pangestu (2020), Maharani (2020), Biniliang et al (2019), Suaidah (2017), Damara (2016), dan Sulistiyawan \& Septiani (2015) yang menyatakan bahwa laba bersih dapat mempengaruhi arus kas operasi di masa mendatang dengan meningkatnya laba bersih maka meningkat pula arus kas operasi di masa mendatang perusahaan sehingga dapat digunakan oleh perusahaan untuk membayar deviden bagi para investor. Berdasarkan uraian diatas maka hipotesis yang diajukan adalah:

\section{$\mathrm{H}_{1}$ : Laba bersih berpengaruh positif signifikan terhadap arus kas masa depan.}




\section{Pengaruh Cash Flow Operation dengan Arus Kas Masa Depan}

Tujuan penyajian informasi arus kas dalam PSAK No. 2 digunakan sebagai dasar untuk menilai kemampuan perusahaan dalam menghasilkan kas dan setara kas serta menilai kebutuhan perusahaan untuk menggunakan kas. Jumlah arus kas yang berasal dari aktivitas operasi merupakan indikator utama yang menentukan apakah operasi perusahaan dapat menghasilkan arus kas yang cukup untuk melunasi pinjaman, memelihara kemampuan operasi entitas, membayar deviden dan melakukan investasi baru tanpa mengandalkan sumber pendanaan dari luar. Artinya disini adalah bahwa jumlah arus kas operasi merupakan suatu hal yang menentukan apakah operasi perusahaan dapat menghasilkan arus kas yang cukup untuk melakukan kegiatan operasional kedepannya.

Besarnya arus kas dari aktivitas operasi dapat menentukan kesuksesan atau kegagalan dari suatu perusahaan. Semakin tinggi arus kas operasi suatu perusahaan, maka kepercayaan investor pada perusahaan akan semakin tinggi. Hal ini didukung oleh penelitian yang dilakukan oleh (Rispayanto, 2013), Sulistiayan \& Septiani (2015), Budiyasa \& Sisdyani (2015) yang menyatakan bahwa semakin tinggi arus kas operasi tahun berjalan maka semakin tinggi arus kas operasi masa mendatang. Berdasarkan uraian diatas maka hipotesis yang diajukan adalah:

$\mathrm{H}_{2}$ : Cash Flow Operation berpengaruh positif signifikan terhadap Arus Kas Masa

\section{Depan.}

Berdasarkan pengembangan hipotesis, maka model penelitian dapat dibuat sebagai berikut:

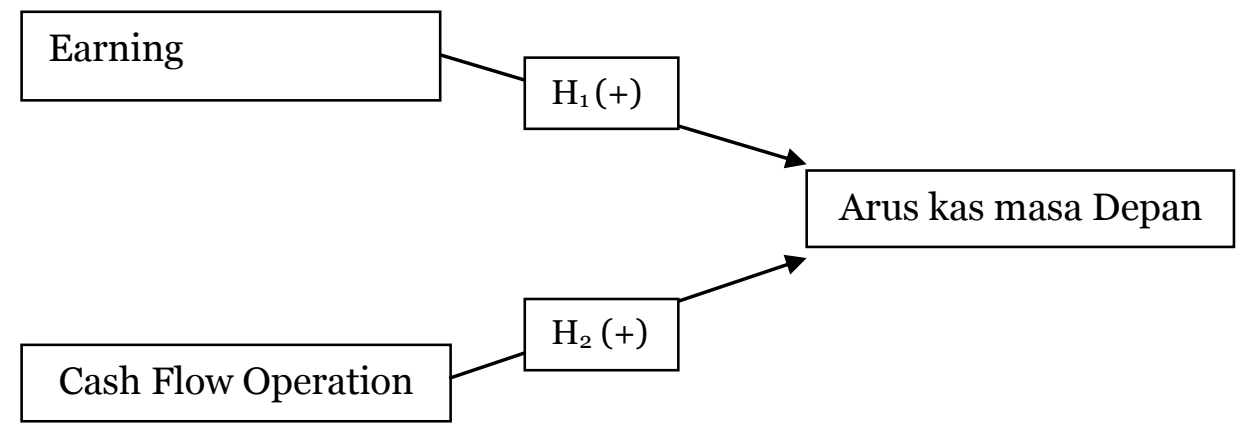

\section{Gambar 1: Kerangka Konseptual}

\section{METODE PENELITIAN}

\section{Populasi dan Sampel}

Penelitian ini dilakukan pada perusahaan sektor consumer goods yang terdaftar di Bursa Efek Indonesia dari tahun 2014 sampai tahun 2018.yang berjumlah 51 perusahaan. 
Karakteristik populasi adalah perusahaan sektor consumer goods yang listing secara berturutturut di Bursa Efek Indonesia dari tahun 2014-2018, mempublikasikan laporan keuangan auditan secara konsisten dan lengkap dari tahun 2014-2018 dan tidak mengalami kerugian.

Sampel dalam penelitian ini menggunakan purposive sampling dengan jumlah sampel sebanyak 27 perusahaan dengan jumlah pengamatan 135. Data dalam penelitian merupakan data sekunder berupa data rasio keuangan, Metode pengumpulan data menggunakan menggunakan teknik dokumentasi yaitu dengan mengumpulkan data laporan keuangan perusahaan dari tahun 2014 sampai tahun 2018 yang dipublikasikan melalui situs www.idx.co.id.

Metode Analisis Data dilakukan dengan regresi data panel mengguakan aplikasi software EViews 11. Syarat pengujian harus memenuhi uji asumsi klasik meliputi uji Normalitas, Uji Autokolerasi, Uji Multikolinearitas dan uji Uji Heteroskedastisitas

\section{Tabel 1}

\section{Operasional Variabel}

\begin{tabular}{|c|c|c|c|}
\hline Variabel Penelitian & Definisi & Indikator & Skala \\
\hline Arus kas masa depan (Y) & $\begin{array}{l}\text { Nilai kas dan setara kasyang } \\
\text { akan dihasilkanperusahaan } \\
\text { dimasa yang akan dating } \\
\text { (Yulianti et al. 2017) }\end{array}$ & $\begin{array}{c}\text { Jumlh arus kas dari aktivitas } \\
\text { operasi satu tahun ke depan } \\
\text { AKMD }=\text { AKO }(t+1)\end{array}$ & Rasio \\
\hline Earning (X2) & $\begin{array}{l}\text { Kenaikan asset dalam satu } \\
\text { periode akibat kegiatan } \\
\text { produktif yg dapat dibagi atau } \\
\text { didistribusikan kepada kreditor, } \\
\text { pemerintah, pemegang saham } \\
\text { tanpa mempengaruhi keutuhan } \\
\text { ekuitas pemegang saham } \\
\text { semula (Ramadhani, 2012) }\end{array}$ & $\begin{array}{c}\text { Jumlah laba bersih setelah } \\
\text { pajak selama tahun berjalan } \\
\text { EARN = laba operasi + } \\
\text { pendapatan lain-lain-beban } \\
\text { lain-lain-beban pajak }\end{array}$ & Rasio \\
\hline Cashflow operation & $\begin{array}{l}\text { Kas yang diperoleh dr aktivitas } \\
\text { utama yang menghasilkan } \\
\text { pendapatan perusahaan dan } \\
\text { aktivitas lain yang bukan } \\
\text { merupakan aktivitas investasi } \\
\text { dan pendanaan (Baridwan } \\
\text { 2004, dalam Kusumawardana } \\
\text { et.al, 2013) }\end{array}$ & $\begin{array}{c}\text { Jumlah arus kas operasi pada } \\
\text { tahun berjalan } \\
\mathrm{CFO}=\text { Arus kas operasi } \\
\text { masuk- arus kas operasi keluar }\end{array}$ & Rasio \\
\hline
\end{tabular}

Sumber: Olah Data Oleh Penulis (2021)

\section{Uji Regresi Berganda}

Menurut (Sugiyono, 2012) analisis regresi linear berganda merupakan regresi yang memiliki satu variabel dependen dan dua atau lebih variabel independen. Persamaan analisis regresi linear berganda dalam penelitian ini yaitu sebagai berikut:

$$
\mathrm{AKMD}_{\mathrm{t}+1}=\alpha+\beta_{1} \mathrm{EARN}_{\mathrm{it}}+\beta_{2} \mathrm{CFO}_{\mathrm{it}}+\mathrm{e}
$$

Keterangan:

$$
\begin{array}{ll}
\mathrm{AKMD}_{\mathrm{t}+1} & =\text { Arus kas operasi masa depan perusahaan pada tahun } \mathrm{t}+1 \\
\alpha & =\text { Koefisien konstanta }
\end{array}
$$


$\beta_{1}, \beta_{2} \quad=$ Koefisien variabel independen

EARN $_{\text {it }} \quad=$ Laba bersih perusahaan pada tahun $\mathrm{t}$

$\mathrm{CFO}_{\text {it }}=$ Arus kas operasi perusahaan pada tahun $\mathrm{t}$

$\mathrm{e} \quad=$ Variabel gangguan

\section{HASIL PENELITIAN DAN PEMBAHASAN}

\section{Hasil Uji Statistik Deskriptif}

Hasil uji statistik deskriptif dapat dilihat pada tabel 2 :

Tabel 2

Statistik Deskriptif

\begin{tabular}{llcl}
\hline Keterangan & Arus Kas Masa Depan & Earning & $\begin{array}{l}\text { Cash } \\
\text { Operation }\end{array}$ \\
\hline Mean & 9,194587 & 9,246475 & 8,789274 \\
Median & 11,70173 & 10,93223 & 11,48102 \\
Maximum & 16,82087 & 16,36200 & 16,54834 \\
Minimum & $-9,187481$ & 0,000000 & $-13,66740$ \\
Standar Deviasi & 5,802840 & 5,514477 & 6,377955 \\
\hline
\end{tabular}

Sumber: Olah Data oleh Penulis (2021)

Berdasarkan tabel 2 menunjukkan bahwa variabel arus kas masa depan memiliki nilai rata-rata sebesar 9.194587. Nilai maksimum arus kas masa depan sebesar 16.82087. Nilai minimum arus kas masa depan sebesar -9.18748. Standar deviasi sebesar 5.802840 dimana standar deviasinya lebih kecil dari nilai rata-ratanya, hal ini menunjukkan adanya fluktuasi nilai arus kas masa depan yang kecil pada perusahaan consumer goods yang menjadi sampel.

Variabel earning memiliki nilai rata-rata sebesar 9.246475. Nilai maksimum earning sebesar 16.36200. Nilai minimum earning sebesar 0.000000. Standar deviasi sebesar 5.514477 dimana standar deviasinya lebih kecil dari nilai rata-ratanya, hal ini menunjukkan adanya fluktuasi nilai earning yang kecil pada perusahaan consumer goods yang menjadi sampel.

Variabel cash flow operation memiliki nilai rata-rata sebesar 8.789274. Nilai maksimum cash flow operation sebesar 16.54834. Nilai minimum cash flow operation sebesar -13.66740. Standar deviasi sebesar 6.377955 dimana standar deviasinya lebih kecil dari nilai rata-ratanya, hal ini menunjukkan adanya fluktuasi nilai cash flow operation yang kecil pada perusahaan consumer goods yang menjadi sampel. 


\section{Hasil Uji Asumsi Klasik}

\section{Uji Normalitas}

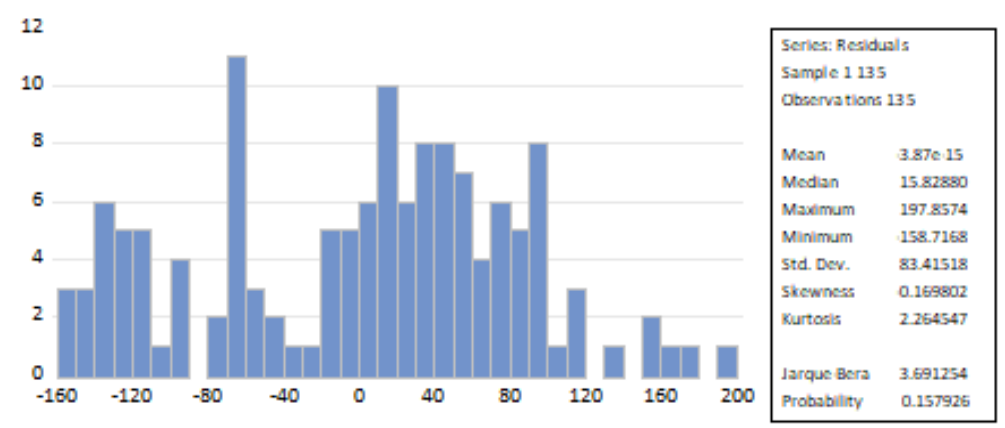

\section{Gambar 1 Hasil Uji Normalitas}

Berdasarkan Gambar 1, dapat dilihat bahwa nilai signifikansi $0.157926>0.05$. Dengan demikian dapat dinyatakan data dari penelitian terdistribusi normal sehingga layak dipakai untuk analisis regresi berganda.

\section{Uji Autokorelasi}

\section{Tabel 3}

\section{Hasil Uji Autokorelasi}

Breusch-Godfrey Serial Correlation LM Test:

Null hypothesis: No serial correlation at up to 1 lags

$\begin{array}{lrlr}\text { F-statistic } & 0,211559 & \text { Prob. F(2,495) } & 0,8096 \\ \text { Obs*R-squared } & 0,437966 & \text { Prob. Chi-Square(2) } & 0,8033 \\ & & & \\ \text { R-squared } & 0,003244 & \text { Mean dependent var } & -3,87 \mathrm{E}-15 \\ \text { Adjusted R-squared } & -0,027425 & \text { S.D dependent var } & 83,41518 \\ \text { S.E. of regression } & 84,55128 & \text { Akaike info criterion } & 11,74893 \\ \text { Sum squared resid } & 929359,5 & \text { Schwarz criterion } & 11,85653 \\ \text { Log likelihood } & -788,0526 & \text { Hannan-Quinn criter. } & 11,79265 \\ \text { F-statistic } & 0,105779 & \text { Durbin-Watson stat } & 1,987700 \\ \text { Prob(F-statistic) } & 0,980322 & & \end{array}$

Sumber: Olah data dengan Menggunakan EViews (2021)

Berdasarkan tabel 3, dapat diketahui bahwa nilai probability dari Obs*R-squared sebesar 0.8033 yang nilainya lebih besar dari 0.05 maka dapat disimpulkan bahwa penelitian ini terbebas dari autokorelasi.

\section{Uji Multikolinearitas}

Berdasarkan Tabel 4, korelasi earning (laba/EARN) dengan cash flow operation (arus kas operasi/CFO) sebesar 0.832321 yang artinya lebih kecil dari 0.9. Kesimpulannya adalah tidak ditemukannya multikolinearitas yang tinggi antara variabel earning (laba/EARN) dengan cash flow operation (arus kas operasi/CFO). 


\section{Tabel 4}

Hasil Uji Multikolinearitas

\begin{tabular}{lcccccc}
\hline \multicolumn{1}{c}{ Variabel } & \multicolumn{3}{c}{ Arus Kas Masa Depan } & \multicolumn{3}{c}{ Cash Flow Operation } \\
& Korelasi & Statistik t & Prob & Korelasi & Statistik t & Prob \\
\hline $\begin{array}{l}\text { Earning } \\
\text { (EARN) }\end{array}$ & 0,080156 & 0,927383 & 0,2554 & 0,832321 & 17,31716 & 0,0000 \\
$\begin{array}{l}\text { Cash Flow } \\
\text { Operation }\end{array}$ & 0,161917 & 1,892289 & 0,0606 & 1,000000 & - & - \\
(CFO) & & & & & & \\
\hline
\end{tabular}

Sumber: Olah data dengan Menggunakan EViews (2021)

\section{Hasil Uji Heterokedastisitas}

\section{Tabel 5}

Hasil Uji Heteroskedastisitas

\begin{tabular}{lrlrr}
\hline $\begin{array}{l}\text { Heteroskedasticity Test: White } \\
\text { Null hypothesis: Homoscedasticity }\end{array}$ & & & \\
\hline F Statistic & 2,064365 & Prob. F (2132) & & 0,1310 \\
Obs*R-squared & 4,094496 & Pro. Chi-Square (2) & & 0,1291 \\
Scaled explained SS & 2,475060 & Pro. Chi-Square (2) & & 0,2901 \\
& & & & \\
Variable & Coefficient & Std. Error & t-Statistic & Prob. \\
C & 5575,098 & 952,5119 & 5,853048 & 0,0000 \\
Earning & $-0,060767$ & 0,126979 & $-0,478560$ & 0,6330 \\
Cash low Operation & 0,121772 & 0,126245 & 0,964556 & 0,3365 \\
\hline
\end{tabular}

Sumber: Olah data dengan Menggunakan EViews (2021)

Berdasarkan Tabel 5 nilai dari probabilitas Chi-Squares pada Obs*R-Squared memiliki nilai 0.1291 lebih besar dari signifikansi $5 \%$ yang berarti bahwa tidak ada masalah heteroskedastisitas dalam penelitian ini.

\section{Uji Hipotesis}

Tabel 6

Hasil Analisis Linear Berganda

\begin{tabular}{|l|l|l|l|l|}
\hline Variable & Coefficient & Std. Error & t-Statistic & Prob. \\
\hline C & 11,05663 & 1,016717 & 10,87484 & 0,0000 \\
\hline EARN & $-0,540938$ & 0,172680 & $-3,132598$ & 0,0022 \\
\hline CFO & 0,357222 & 0,147427 & 2,423044 & 0,0171 \\
\hline & & R-squared & 0,300767 \\
\hline & Adjusted R-squared & 0,116063 \\
\hline & F-statistic & 1,628378 \\
\hline & Prof(F-statistic) & 0,040279 \\
\hline
\end{tabular}

Sumber: Olah data dengan Menggunakan EViews (2021)

Berdasarkan tabel 6, koefisien dari masing-masing variabel dan konstanta yang menjadi observasi dalam penelitian ini adalah konstanta 11.05663, koefisien (EARN) 0.540938 dan koefisien (CFO) 0.357222. Dari penjelasan di atas, maka diperoleh model persamaan regresi sebagai berikut:

$$
\mathrm{AKMD}=11.05663 \alpha-0.540938 \mathrm{EARN}+0.357222 \mathrm{CFO}+\mathrm{ei}
$$


Pada persamaan diatas dapat dilihat bahwa nilai konstanta sebesar 11.05663, hal ini berarti bahwa apabila variabel earning (EARN) dan cash flow operation (CFO) bernilai 0, maka variabel arus kas masa depan (AKMD) akan tetap konstan sebesar 11.05663.

Selanjutnya nilai koefisien variabel earning (EARN) sebesar -0.540938, hal ini berarti bahwa apabila earning (EARN) menurun 1\%, maka arus kas masa depan (AKMD) akan menurun sebesar-0.540938. Kemudian nilai koefisien variabel cash flow operation (CFO) sebesar 0.357222 , hal ini berarti bahwa apabila cash flow operation (CFO) meningkat $1 \%$, maka arus kas masa depan (AKMD) akan meningkat sebesar 0.357222. Maka dapat ditarik kesimpulan hasil dari pengujian hipotesis pada penelitian ini menggunakan fixed effect model (FEM) menunjukkan bahwa earning (EARN) memiliki nilai probability sebesar 0.0022 . Sementara itu tingkat signifikansi sebesar 0,05 . Oleh karena probability $(0.0022)<(0,05)$ sehingga $\mathrm{H}_{1}$ diterima yang artinya earning (EARN) secara signifikan berpengaruh negatif terhadap arus kas masa depan (AKMD). Kemudian hasil dari fixed effect model (FEM) menunjukkan cash flow operation (CFO) memiliki nilai probability sebesar 0.0171 . Sementara itu tingkat signifikansi sebesar 0,05 . Oleh karena itu probability $(0.0171)<(0,05)$ sehingga $\mathrm{H}_{2}$ diterima yang artinya cash flow operation (CFO) secara signifikan berpengaruh positif terhadap arus kas masa depan (AKMD).

Selanjutnya hasil dari fixed effect model (FEM) menunjukkan earning (EARN) dan cash flow operation (CFO) memiliki nilai probability (F-Statistic) sebesar 0.040279. Sementara itu, tingkat signifikansi sebesar 0,05. Oleh karena itu, probability (F-Statistic) $(0.040279)<(0,05)$ sehingga $\mathrm{H}_{3}$ diterima yang artinya earning $(\mathrm{EARN})$ dan cash flow operation (CFO) secara bersamaan berpengaruh positif dan signifikan terhadap arus kas masa depan (AKMD). Dan yang terakhir adalah koefisien determinasi $\left(\mathrm{R}^{2}\right)$, nilai $R$-squared yang dihasilkan dari model regresi sebesar 0.300767 yang berarti bahwa earning dan cash flow operation mempengaruhi arus kas masa depan pada perusahaan-perusahaan sektor consumer goods sebesar 30,07\%, sedangkan sisanya 69,93\% dipengaruhi oleh variabel-variabel lain diluar penelitian ini.

\section{Pengaruh Earning Terhadap Arus Kas Masa Depan}

Berdasarkan tabel 6, diketahui bahwa variabel earning (EARN) berpengaruh negatif dan signifikan terhadap arus kas masa depan (AKMD) pada perusahaan sektor consumer goods. Hal ini menunjukkan bahwa semakin tinggi earning (EARN) akan berdampak pada penurunan arus kas masa depan (AKMD). Begitu juga sebaliknya, semakin rendah nilai earning (EARN) maka akan berdampak pada kenaikan arus kas masa depan (AKMD). 
Soemarso (2004) menyatakan laba bersih sebagai hasil pengurangan antara seluruh pendapatan dengan beban yang timbul dari kegiatan operasional maupun non operasional perusahaan. Karena laba bersih bersifat akrual dan berasal dari laba sebelum pajak ditambah pendapatan lain-lain dan dikurangi dengan beban lain-lain seperti pendapatan bunga, beban bunga maupun beban pajak. Dimana, pendapatan bunga yang diperoleh perusahaan terkandung dalam laporan laba rugi perusahaan yang berasal dari pokok pinjaman dan bunga. Disamping itu persepsi dan keputusan terhadap laba yang berbeda disetiap perusahaan yang nantinya akan menjadi kelemahan suatu laba terhadap pengakuan arus kas masa depan. Ketika perusahaan mengalami suatu peningkatan laba maka meningkat pula deviden perusahaan. Setelah dilakukan Rapat Umum Pemegang Saham (RUPS) maka akan didapatkan keputusan perlakuan terhadap laba tersebut. Apakah laba akan dibagikan kepada para pemegang saham atau digunakan untuk kegiatan operasional. Jika laba dibagikan kepada para pemegang saham maka secara otomatis akan berdampak pada arus kas. Begitu pula jika laba dijadikan investasi terhadap operasional perusahaan, maka akan mengakibatkan produksi yang meningkat pula. Produksi perusahaan yang meningkat belum tentu diikuti dengan penjualan yang juga meningkat karena ada banyak faktor yang menyebabkan peningkatan dan juga penurunan penjualan salah satunya ialah inflasi. Hal inilah yang nantinya menyebabkan ketika laba meningkat maka arus kas masa depan akan mengalami penurunan.

Salah satu penyebab penurunan laba adalah menurunnya penjualan, ketika penjualan menurun artinya perusahaan memiliki persediaan sisa produksi. Mengingat kembali bahwa perusahaan mempunyai kebijakan minimal produksi, maka hal tersebut menyebabkan bertambahnya lagi persediaan produksi perusahaan. Selanjutnya ketika laba turun, maka pihak manajemen perusahaan akan menyusun strategi baru untuk memaksimalkan penjualan. Hal inilah yang menyebabkan ketika laba turun maka meningkatnya arus kas masa depan perusahaan. Hal tersebut dapat dikaitkan dengan teori sinyal dimana informasi laba perusahaan bisa digunakan oleh pihak manajemen untuk menilai kebutuhan perusahaan serta menilai risiko atas pencapaian arus kas masa depan.

Hasil penelitian ini mendukung penelitian yang dilakukan oleh Damara (2016) yang menyatakan bahwa laba bersih dapat mempengaruhi arus kas operasi di masa mendatang sehingga dapat digunakan oleh perusahaan untuk membayar deviden bagi para investor.

\section{Pengaruh Cash Flow Operation Terhadap Arus Kas Masa Depan}

Berdasarkan tabel 6, diketahui bahwa variabel cash flow operation (CFO) berpengaruh positf dan signifikan terhadap arus kas masa depan (AKMD) pada perusahaan 
sektor consumer goods. Hal ini menunjukkan bahwa semakin tinggi cash flow operation (CFO) akan berdampak pada peningkatan arus kas masa depan (AKMD). Begitu juga sebaliknya, semakin rendah nilai cash flow operation (CFO) maka akan berdampak pada penurunan arus kas masa depan (AKMD).

Kieso (2008) menyatakan bahwa "kas yang dihasilkan dari aktivitas operasi perusahaan dianggap sebagai ukuran terbaik atas kemampuan perusahaan menghasilkan uang dalam rangka going concern". Menurut Wanti (2012) dalam Rispayanto (2013), arus kas operasi mempunyai kemampuan sebagai prediktor arus kas operasi di masa depan, hal ini karena arus kas aktivitas operasi cukup untuk memelihara kemampuan operasional perusahaan, membayar deviden, dan melakukan investasi baru, sehingga dimungkinkan penggunaan keuntungan perusahaan untuk menutupi arus kas mendatang. Dalam PSAK No. 2 tahun 2009 menyatakan bahwa "pengguna laporan keuangan dapat menggunakan informasi yang berasal dari arus kas operasi untuk mengevaluasi perubahan dalam aset bersih, struktur keuangan maupun kinerja keuangan perusahaan”. Melalui arus kas operasi pengguna laporan keuangan dapat mengembangkan model untuk menilai dan membandingkan nilai sekarang dari arus kas operasi masa depan.

Arus kas operasi dapat digunakan sebagai indikator yang menunjukkan apakah kegiatan operasional perusahaan memiliki kas yang cukup untuk melunasi pinjaman, pembayaran dividen dan melakukan investasi baru tanpa mengandalkan sumber pendanaan dari luar (Rispayanto, 2013). Oleh karena itu arus kas operasi dapat digunakan sebagai prediktor dalam memprediksi arus kas operasi di masa depan agar investor, kreditor, maupun pengambil keputusan lainnya dapat mengambil keputusan yang tepat dengan menggunakan informasi yang berhubungan dengan arus kas operasi masa depan sebagai pertimbangan (Rispayanto, 2013).

Perusahaan yang menyajikan informasi arus kas operasi positif akan dianggap sebagai sinyal baik (good news) oleh investor. Hal ini dikarenakan arus kas operasi bernilai positif menunjukkan bahwa perusahaan tidak akan kesulitan keuangan di masa mendatang sehingga akan berdampak positif pada keputusan investasi yang akan dilakukan oleh investor.

Hasil penelitian ini mendukung penelitian yang dilakukan oleh (Rispayanto, 2013) yang menyatakan bahwa semakin tinggi arus kas operasi tahun berjalan maka semakin tinggi arus kas operasi mendatang. Namun hasil penelitian ini bertentangan dengan penelitian yang dilakukan oleh (Kusumawardana et al, 2013) yang menyebutkan bahwa arus kas dari aktivitas operasi tidak berpengaruh terhadap arus kas masa depan. 


\section{SIMPULAN}

Berdasarkan hasil penelitian dan pembahasan yang telah diuraikan dapat ditarik kesimpulan bahwa: cash flow operation berpengaruh positif dan signifikan terhadap arus kas masa depan perusahaan, sementara itu Earning berpengaruh negatif dan signifikan terhadap arus kas masa depan perusahaan. Secara simultan Earning dan cash flow operation berpengaruh positif dan signifikan terhadap arus kas masa depan perusahaan.

Adapun keterbatasan dalam penelitian yaitu sampel yang digunakan hanyaperusahaan consumer goods sehingga hasil penelitian belum dapat digeneralisasi dan periode pengamatan hanya 5 tahun yaitu dari tahun 2014 sampai dengan tahun 2018.

Penelitian selanjutnya diharapkan menggunakan kategori sektor selain consumer goods dengan menambah rentang waktu pengamatan sehingga diperoleh hasil yang lebih akurat dalam memprediksi arus kas masa depan. Menambah variabel lainnya seperti laba kotor, laba operasi, arus kas investasi dan arus kas pendanaan sehingga dapat memperluas hasil penelitian.

\section{REFERENSI}

Binilang, G. D. C., Ilat, V., \& Mawikere, L. M. (2019). Pengaruh laba bersih, perubahan piutang usaha, perubahan utang usaha dan perubahan persediaan terhadap arus kas operasi di masa depan pada perusahaan yang terdaftar dalam indeks lq45 di bursa efek Indonesia Tahun 2011-2015. Jurnal EMBA: Jurnal Riset Ekonomi, Manajemen, Bisnis dan Akuntansi, 5(2).

Budiyasa, A., \& Sisdyani, E. (2015). Analisis Laba Dan Arus Kas Operasi Sebagai Prediktor Arus Kas Di Masa Depan. E-Jurnal Akuntansi.

Damara, T. (2016). Pengaruh Kemampuan Laba dan Arus Kas Operasi dalam Memprediksi Arus Kas Operasi Masa Depan (StudiEmpirisPada Perusahaan Manufaktur yang Terdaftar di BEI). Jurnal Universitas Negeri Padang.

Ghozali, I. (2011). Aplikasi Analisis Multivariate dengan menggunakan SPSS. In Gramedia.

Harahap, S. S. (2015). Analisis Kritis atas Laporan Keuangan (Edisi 1-10). Rajawali Pers.

Harisnawati, R., Ulum, I., \& Syam, D. (2017). Pengaruh Intellectual Capital Performance Terhadap Intensitas Pelaporan Modal Intelektual. Jurnal Reviu Akuntansi Dan Keuangan.

Ikhsan, A., Aziza, N., Hayat, A., Lesmana, S., Albra, W., Khadaffi, M., dan Oktaviani, A. (2018). Metodologi Penelitian Bisnis. Medanatera.

Kieso, D. E., Weygandt, J. J., \& Warfield, T. D. (2007). Akuntansi Intermediate, Edisi Keduabelas, Jilid 1. Penerbit Erlangga. 
Kusumawardana, S. dan L. (2013). Pengaruh Laba dan Arus Kas Terhadap Kemampuan Memprediksi Arus Kas Masa Depan (Studi Pada Perusahaan Yang Masuk LQ45 di Bursa Efek Indonesia). Jurnal Pro Bisnis, Vol.6 No.2, Hal. 14-25.

Maharani, Y. (2020). Model Prediksi Arus Kas di Masa Depan (Studi Empiris pada Perusahaan Telekomunikasi yang Terdaftar di BEI). Jurnal Ilmu Sosial, Manajemen, Akuntansi dan Bisnis, 1(1), 1-13.

Nany, M. (2013). Analisis Kemampuan Prediksi Arus Kas Operasi (Studi Pada Bursa Efek Indonesia). Jurnal Dinamika Akuntansi, Vol.5 No.1, Hal. 35-46.

Pangestu, M. (2020). Analisis Kemampuan Informasi Laba dan Arus Kas dalam Memprediksi Arus Kas Masa Depan. Berkala Akuntansi dan Keuangan Indonesia, 5(2), 132-152.

Prastowo D., M.M., A. (2015). Analisis Laporan Keuangan Konsep dan Aplikasi. In Analisis Laporan Keuangan.

Rispayanto, S. (2013). Pengaruh Laba Kotor, Laba Operasi, Laba Bersih, dan Arus Kas Operasi Masa Mendatang (Studi Empiris Pada Perusahaan Manufaktur yang Terdaftar di BEI). Jurnal Akuntansi.

Simamora, H. (2012). Akuntansi Manajemen. Edisi III. In Akuntansi Manajemen.

Soemarso, S. (2004). Akuntansi Suatu Pengantar (Edisi Lima). Salemba Empat.

Suaidah, Y. M. (2017). Kemampuan Informasi Komponen Arus Kas dan Laba dalam Memprediksi Arus Kas Masa Depan. Eksis: Jurnal Riset Ekonomi dan Bisnis, 12(2), 161-170.

Sugiyono. (2013). Metode Penelitian Pendidikan Pendekatan Kuantitaif, Kualitatif, dan R\&D. Bandung CV alfabeta. Metode Penelitian Pendidikan Pendekatan Kuantitaif, Kualitatif, Dan $R \& D$.

Sulistyawan, W., \& Septiani, A. (2015). Pengaruh laba bersih, arus kas operasi dan komponen-komponen akrual dalam memprediksi arus kas operasi di masa depan. Diponegoro journal of accounting, 4(4), 460-470.

Sumbramanyam, K.R., dan John, J. W. (2010). Analisis Laporan Keuangan. Salemba Empat.

Susanti, S., \& Elen, T. (2021). Faktor-Faktor Yang Mempengaruhi Prediksi Arus Kas Masa Depan Pada Perusahan Manufaktur Sektor Konsumsi. Jurnal Akuntansi, Keuangan, Pajak dan Informasi (JAKPI), 1(1), 45-62.

Triyono. (2011). Dampak Kualitas Laba Terhadap Kemampuan Memprediksi Laba, Arus Kas dan Komponen Akrual. In Simposium Nasional Akuntansi xiv Aceh 2011. Universitas Syiah Kuala, Aceh.

Wanti, F.K.P. (2012). Kemampuan Laba Bersih, Arus Kas Operasi, dan Rasio Piutang untuk Mempengaruhi Arus Kas Masa Mendatang pada Perusahaan Food And Beverage di Bei. In Berkala Ilmiah Mahasiswa Akuntansi Widya Mandala.

Wartini. (2013). Pengaruh Laba Kotor, Laba Operasi dan Laba Bersih dalam Memprediksi 
Arus Kas Aktivitas Operasi Di Masa Mendatang. Jurnal Universitas Maritim Raja Aali Haji.

Wijaya, A. P. (2013). Analisis rasio keuangan dalam merencanakan pertumbuhan laba: perspektif teori signal. Kajian Ilmiah Mahasiswa Manajemen.

Yunia, D., \& Ibrahim, M. I. (2021). Memprediksi Arus Kas Dengan Laba Bersih Dan Total Pendapatan Komprehensif Lain. Monex: Journal of Accounting Research-Politeknik Harapan Bersama Tegal, 10(1), 64-72. 